\title{
Geo(Im)pulse
}

\section{The echinoid Holaster laevis from the Albian (Lower Cretaceous) of the Winterswijk area, eastern Netherlands}

\author{
J.W.M. Jagt ${ }^{1,{ }^{*}} \&$ H.W. Oosterink ${ }^{2}$ \\ 1 Natuurhistorisch Museum Maastricht, de Bosquetplein 6-7, NL-6211 KJ Maastricht, the Netherlands. \\ 2 Hortensialaan 64, NL-7101 XH Winterswijk, the Netherlands. \\ * Corresponding author. Email: john.jagt@maastricht.nl.
}

Manuscript received: April 2010, accepted: November 2010

\begin{abstract}
A single internal mould of the holasterid echinoid Holaster laevis (Brongniart, 1822) constitutes the first record of this species from the upper portion ('Upper Holland Marl') of the Holland Formation (Rijnland Group), of middle-late Albian age, in the Winterswijk area (eastern Netherlands). The geographic range of $H$. laevis can thus be extended to this part of western Europe, with previous records from southern England (Wiltshire, Devon) and the Département Ain in east-central France.
\end{abstract}

Keywords: Echinoidea, Holasteridae, Albian, the Netherlands

\section{Introduction}

At various places within the hamlet of Kotten, east of Winterswijk (Achterhoek, province of Gelderland; eastern Netherlands), there are small outcrops of mid-Cretaceous (Albian-Cenomanian) strata, especially along the courses of the Boven Slinge and Bekerinkbeek, the latter near the Bekerink (Beekering) farmstead (Fig. 1). Amongst other macrofossils, these levels have yielded the coleoid Neohibolites minimus (Miller, 1826), index of the middle Albian minimus Beds (see e.g. Spaeth, 1991; Mutterlose, 1997), although there are also records of that species from the lower upper Albian in northern Germany (Lehmann et al., 2008). Stapert (1974, pp. 66-70) recorded from the Bekerinkbeek a number of bivalve species, isolated shark teeth, hoplitid ammonites and N. minimus, all originating from green glauconitic clay and greenish or greyish sandstone with a variable glauconite content. On the evidence of hoplitid ammonites, Stapert (1974, p. 70) favoured a middle Albian date, an age assignment accepted subsequently by Witte et al. (1992, figs 1,2) for sections exposed in and along the Bekerinkbeek.

The specimen described below was collected loose from a dump in a field just east of the Beekering farmstead (Fig. 1), the material having originated from the Bekerinkbeek but any depth indication is lacking. The whitish internal mould allows the original matrix to be determined as a fairly indurated, greenish grey, poorly glauconitic marlstone. As such, this might correspond to what Witte et al. (1992, p. 37) referred to as the 'onderste Flammenmergel', of late Albian age, but we cannot confirm this beyond doubt.

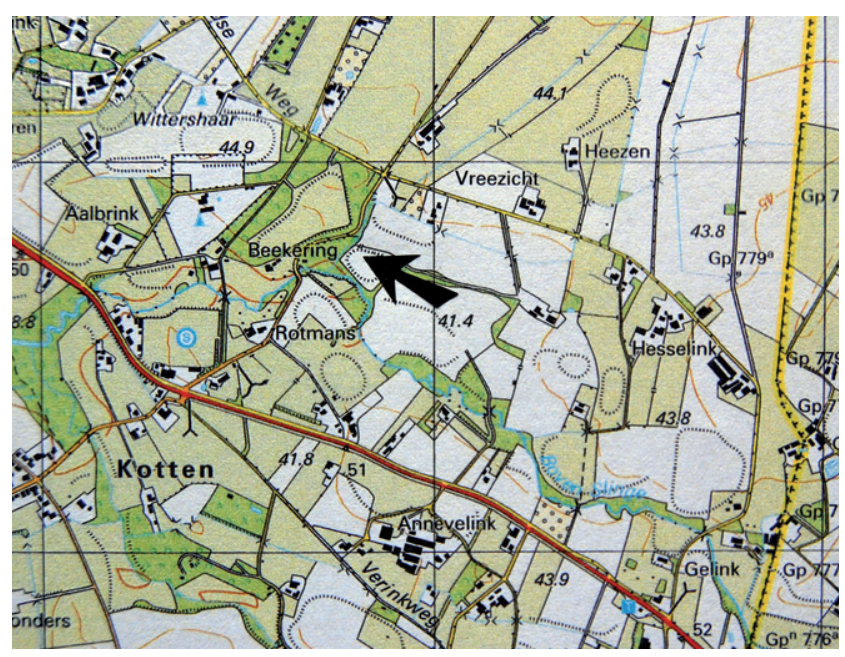

Fig. 1. Map of Kotten, east of Winterswijk, with arrow marking the position of the dump which yielded the echinoid specimen described herein. 
Recent studies (Herngreen et al., 2000, p. 82, table 5, fig. 6) have also listed the age of strata exposed in the Bekerinkbeek as middle Albian, but, more importantly, have documented from the borehole Kotten 41E-330 (co-ordinates 249.830/440.376, sunk in 1998), a continuous interval of strata of Aptian, Aptian/Albian and middle Albian to middle Cenomanian age. Overall, glauconite content appears to decrease in marls of late Albian age, so that the present specimen might have come from such levels.

\section{Systematic palaeontology}

Family Holasteridae Pictet, 1857

Genus Holaster Agassiz, 1836

\section{Type species}

Spatangus nodulosus Goldfuss, 1829, by subsequent designation of Savin (1905).

\section{Holaster laevis (Brongniart, 1822)}

Figs 2, 3 .

*1822 Spatangus laevis de Luc; Brongniart, pp. 97, 399; pl. 9, fig. $12 \mathrm{a}, \mathrm{b}$.

2003 Holaster laevis (Brongniart, 1822); Smith \& Wright, p. 535, figs 219, 220, 223; pl. 172, figs 1-15 (with additional synonymy).

\section{Material}

A single, slightly crushed internal mould, no. 0242-21363 in the collections of the Museum Freriks (Winterswijk; ex H.W. Oosterink Collection, no. 221).

\section{Description}

Test rather small (test width, as preserved, $33.2 \mathrm{~mm}$; test length $34.5 \mathrm{~mm}$; L/W ratio 1.04), near-circular in outline, widest point at centre; test height, as preserved, $10.5 \mathrm{~mm}$ (H/L ratio 0.30$)$; test uniformly domed aborally in lateral view, posterior portion crushed, but broadly truncate; frontal groove only faint, not extending to oral surface; apical disc near centre, of standard holasteroid type, with four gonopores, all open; ambulacrum III flush aborally, but weakly sunken towards ambitus and groove almost absent adorally; pore pairs in ambulacrum III small, oblique and apparently undifferentiated; paired ambulacra subpetaloid, flush and with elongate and near-circular pore pairs; anterior and posterior petals near straight; apparent flexure in latter due to crushing (Fig. 2A); ambitus sharply rounded, close to base (Fig. 2B); peristome large, D-shaped, facing downwards (height and width c. 4 and $6 \mathrm{~mm}$, respectively), with enlarged pore pairs for phyllode tube feet (Fig. 2B), whole area in front of peristome slightly sunken (Fig. 2B); base flat; plastron meridosternous (Figs 2B,3), although sutures barely

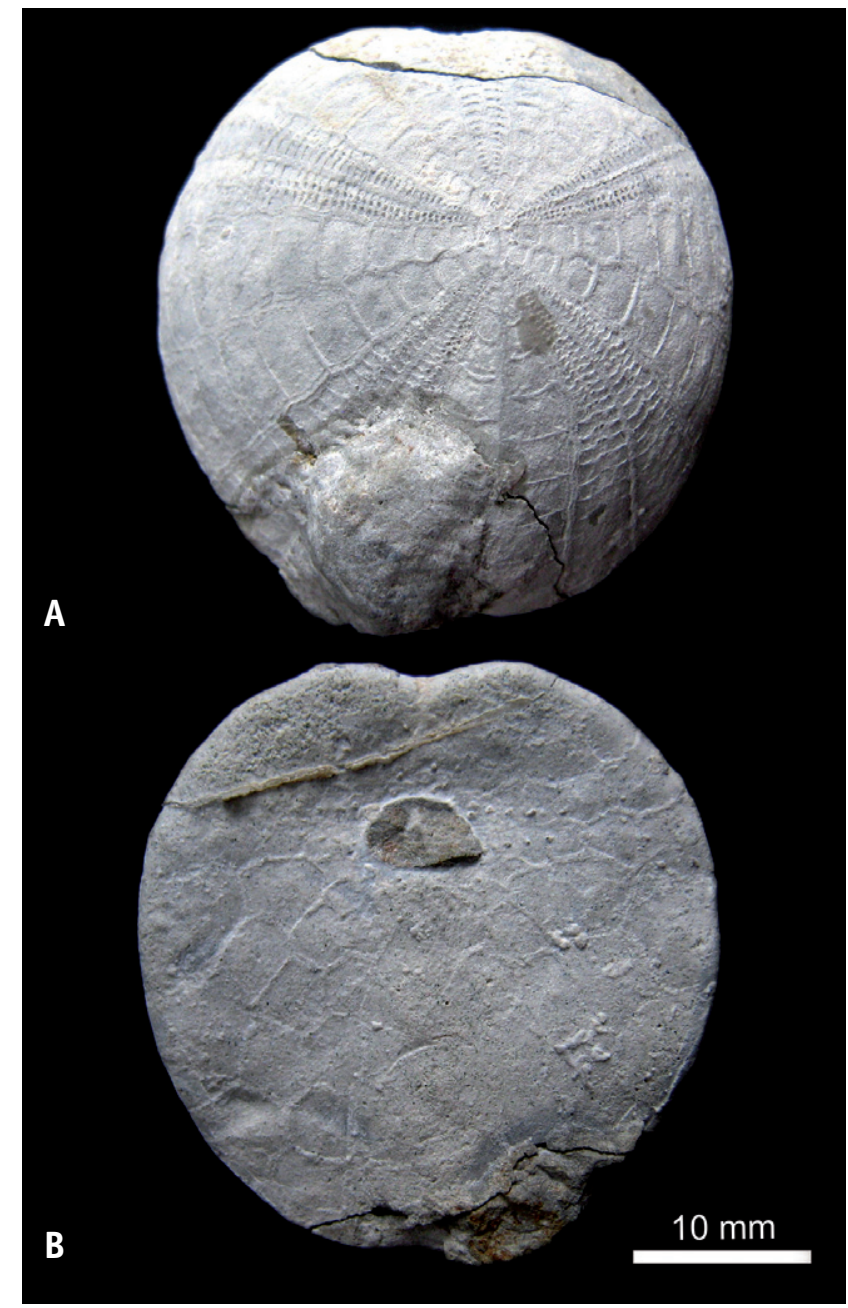

Fig. 2. Holaster laevis (Brongniart, 1822) in apical and oral views, respectively (collections of Museum Freriks, Winterswijk, no. 0242-21363; leg. H.W. Oosterink).

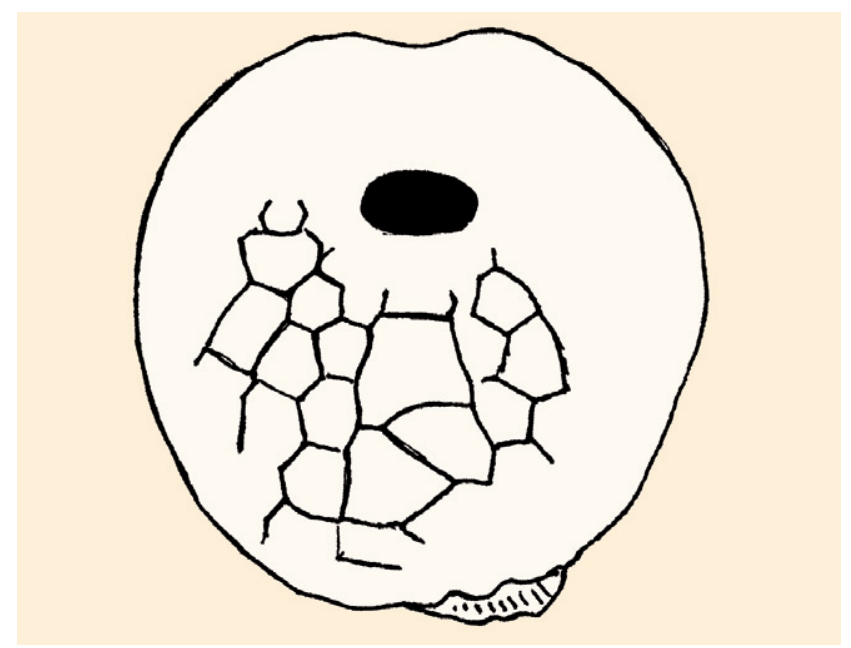

Fig. 3. Line-drawing of plastronal structure of the same specimen (see Fig. 2B) of Holaster laevis (Brongniart, 1822). Not to scale.

visible, relatively broad ( $8.5 \mathrm{~mm}$ between plates $5 . \mathrm{b} .2$ and 5.b.3; compare Smith \& Wright, 2003, fig. 223); periproct not preserved; no tubercles preserved. 


\section{Discussion}

Although identification of internal moulds of echinoids generally is fraught with difficulties, test proportions (in particular L/W ratio) and plastron structure and width of the present specimen match well-preserved material from the upper Albian and lowermost Cenomanian of Wiltshire and Devon (Smith in Smith et al., 1988, pp. 142-146, text-fig. 55; pl. 29, figs 1-4; Smith \& Wright, 2003) and east-central France (Smith \& Wright, 2003). Despite the fact that crushing prevents a proper assessment of test profile and that plastronal sutures cannot be made out fully (see Figs 2B, 3), an affiliation with $H$. laevis is favoured here. For differences between this species, the co-occurring $H$. nodulosus (Goldfuss, 1829) and the slightly younger $H$. trecensis Leymerie, 1842, reference is made to Smith \& Wright (2003).

The type of $H$. laevis is from upper Albian greensands at Perte-du-Rhône, département Ain (east-central France), from which Smith \& Wright (2003, p. 535, pl. 172, figs 1-4) examined and illustrated topotype material. Those authors also noted that this species was moderately common, but that most specimens were crushed to some extent, so that measurements could not be but approximate (see above; in particular test height). The known range of $H$. laevis in southern England is Upper Greensand (upper Albian, Stoliczkaia dispar Zone of authors) and overlying Cambridge Greensand (remanié internal moulds) to lower Cenomanian. Whether or not 'Holaster laevis (de Luc)' of Kaever et al. (1979, p. 281, pl. 5/9; photo plate 8, upper figure) is the same species can only be determined by examination of the plastron structure. Those authors indicated it to be of Neocomian age (unspecified), noting it from the Barler Berg near Ahaus (of Aptian age) and the Barenberg near Borgholzhausen.

\section{Conclusion}

Despite the fact that only a single internal mould is available, which lacks precise stratigraphic data other than 'Albian' at that, we favour affiliation with $H$. laevis on the basis of test proportions, relative plastronal width and plastronal structure. For now, we assume the specimen to be of 'onderste Flammenmergel' age (i.e., late Albian), in correspondence with well-dated occurrences in southern England and east-central France, but cannot rule out completely a middle Albian date.

\section{Acknowledgements}

We thank W. van Rijsselt (Maastricht), Dr A.S. Schulp (Natuurhistorisch Museum Maastricht) and Dr E.A. Jagt-Yazykova (Uniwersytet 0polski, 0pole) for production and processing of photographs and Dr A. Kroh (Naturhistorisches Museum Wien) and Dr A.B. Smith (The Natural History Museum, London) for insightful reviews.

\section{References}

Agassiz, L., 1836. Prodrome d'une monographie des radiaires ou échinodermes. Mémoires de la Société des Sciences Naturalles de Neuchâtel 1: 168-199.

Brongniart, A., 1822. Sur quelques terrains de Craie hors du Bassin de Paris. In: Cuvier, G. \& Brongniart, A. (eds): Description géologique des environs de Paris. G. Dufour \& E. d'0cagne (Paris): 80-101.

Goldfuss, A., 1829. Petrefacta Germaniae tam ea, quae in museo universitatis regiae Borussicae Fridericiae Wilhelmiae Rhenanae servantur quam alia quae cunque in museis hoeninghusiano, muensteriano aliisque extant, iconibus et descriptionibus illustrata. Abbildungen und Beschreibungen der Petrefacten Deutschlands und der angränzenden Länder, unter Mitwirkung des Herrn Grafen Georg zu Münster. Arnz \& Co. (Düsseldorf): 77-164, pls. 26-50.

Herngreen, G.F.W., Van den Bosch, M. \& Lissenberg, T., 2000. Nieuwe inzichten in de stratigrafische ontwikkeling van Jura, Krijt en Onder-Tertiair in de Achterhoek. Grondboor \& Hamer 54: 70-92.

Kaever, M., Oekentorp, K. \& Siegfried, P., 1979. Fossilien Westfalens. Teil I: Invertebraten der Kreide ( $5^{\text {th }}$ edition). Münstersche Forschungen zur Geologie und Paläontologie 33/34: 1-364.

Lehmann, J., Tröger, K.-A. \& Owen, H.G., 2008. Ammonites and associated macrofauna from the early Late Albian of the Zippelsförde 1/64 core, NE-Germany. Acta Geologica Polonica 58: 437-453.

Leymerie, A., 1842. Suite du Mémoire sur le terrain Crétacé du Département de l'Aube. Mémoires de la Société géologique de France 5: 1-34.

Miller, J.S., 1826. Observations on the genus Actinocamax. Transactions of the Geological Society of London (2)2: 63-67.

Mutterlose, J., 1997. Lower Cretaceous. In: Mutterlose, J., Wippich, M.G.E. \& Geisen, M. (eds): Cretaceous depositional environments of NW Germany. Bochumer geologische und geotechnische Arbeiten 46: 7-12.

Pictet, F.J., 1857. Traité de paléontologie ou histoire naturelle des animaux fossiles, 2. J.-B. Baillière (Paris): 1-727.

Savin, L., 1905. Révision des échinides du département de l'Isère. Bulletin de la Société statistique des Sciences naturelles et des Arts industrielles du Département de l'Isère (4)8: 109-315.

Smith, A.B., Paul, C.R.C., Gale, A.S. \& Donovan, S.K., 1988. Cenomanian and Lower Turonian echinoderms from Wilmington, south-east Devon, England. Bulletin of the British Museum (Natural History), Geology series 42: 1-245, 51 pls.

Smith, A.B. \& Wright, C.W., 2003. British Cretaceous echinoids. Part 7, Atelostomata, 1. Holasteroida. Monograph of the Palaeontographical Society London 156 (619): 440-568, pls 139-182.

Spaeth, C., 1991. Neohiboliten-Leitarten der mittleren Kreide von Helgoland. In: Schmid, F. \& Spaeth, C. (eds): Die Kreide der Nordseeinsel Helgoland. Geologisches Jahrbuch A120: 281-287.

Stapert, D., 1974. Over het onderkrijt (sic) in de omgeving van Winterswijk. Grondboor \& Hamer 28: 62-77.

Witte, L., Lissenberg, T. \& Schuurman, H., 1992. Ostracods from the Albian/Cenomanian boundary in the Achterhoek area (eastern part of the Netherlands). Scripta Geologica 102: 33-84. 